Article

\title{
Enhancing the Practical Utility of Risk Assessments in Climate Change Adaptation
}

\author{
Angela Connelly ${ }^{1, *}$, Jeremy Carter ${ }^{1}$, John Handley ${ }^{1}$ and Stephen Hincks ${ }^{2}$ \\ 1 Department of Planning and Environmental Management, The University of Manchester, Manchester M13 \\ 9PL, UK; jeremy.carter@manchester.ac.uk (J.C.); john.handley@manchester.ac.uk (J.H.) \\ 2 Department of Urban Studies and Planning, University of Sheffield, Sheffield S10 2TN, UK; \\ s.hincks@sheffield.ac.uk \\ * Correspondence: angela.connelly-2@manchester.ac.uk; Tel.: +44-161-275-0809
}

Received: 26 March 2018; Accepted: 22 April 2018; Published: 2 May 2018

check for updates

\begin{abstract}
In 2012, the Intergovernmental Panel on Climate Change (IPCC) moved from a vulnerability to a risk-based conception of climate change adaptation. However, there are few examples of work that translates this approach into climate change adaptation practice, in order to demonstrate the practical utility of following a risk-based approach to adapting to climate change. The paper explores critically the differing conceptions of vulnerability and risk across the literature relating to disaster risk management and climate change adaptation. The paper also examines a selection of spatially focused climate change vulnerability and risk assessment methodologies in this context. In doing so, we identify issues with the availability of spatial data to enable spatial risk-based climate change assessments. We argue that the concept of risk is potentially favorable in helping cities to understand the challenges posed by climate change, identify adaptation options, and build resilience to the changing climate. However, we suggest that change is needed in the way that practitioners and policymakers engage with risk-based concepts if they are to be embed into climate change adaptation activities.
\end{abstract}

Keywords: climate change adaptation; climate resilience; climate risk; spatial planning; climate change risk assessment; climate change vulnerability assessment

\section{Introduction}

Climate change adaptation features prominently in discussions on the realization of sustainable development. In their most recent report, the Intergovernmental Panel on Climate Change (IPCC) notes that future development should 'combine adaptation and mitigation to realize the goal of sustainable development' [1]. This is re-emphasized by the United Nations Environment Programme (UNEP) which suggests that 'urgent action to combat climate change and minimize its disruptions is integral to the successful implementation of the Sustainable Development Goals' [2]. The need for urban areas to live within the limits of dynamic natural resources has long been seen as critical for sustainable economic development given that natural processes underpin urban production [3,4]. Whilst climate change adaptation can contribute to wider sustainability goals, in practice many organizations and groups remain locked in silos. A common language and harmonized conceptual approach may help to promote the consideration of climate change adaptation into policy and, in particular, land use decisions which are critical to ensuring that urban areas are climate resilient. However, those in the climate change adaptation community have largely used 'vulnerability' as their frame for understanding and responding to climate change which is at odds with more mainstream understandings of exposure and disaster where the preferred term is 'risk' $[5,6]$. 
Identifying and assessing risk is common across a number of disciplines from health sciences to disaster risk management to critical infrastructure protection. Since 2012, the main scientific organization that leads on climate change, the Intergovernmental Panel on Climate Change (IPCC) has reframed climate change adaptation to focus on risk rather than vulnerability. Such a move intends to harmonize the climate change adaptation community with those working in allied disciplines, such as disaster risk management $[7,8]$. There is a further supposition that the risk-based concept can help to shift the focus from top-down, science-first vulnerability assessments to risk assessments that can better involve a range of stakeholders and can help to consider climate change as one risk along with many other challenges [9]. Reframing climate change assessments towards risk, as opposed to impact and vulnerability, may also help to prioritize climate change and assist with communicating the climate change challenge [10].

The need to bring disaster risk managers closer to climate change adaptation specialists is widely recognized, but has been hampered by conceptual misalignments. This has implications for the way that climate change, and associated risks, are managed in cities through spatial planning decisions. The interaction of socio-economic, climatic and physical factors has significant land-use consequences as well as overall questions regarding the distribution of resources and requires integration and spatially oriented strategies [11,12]. Spatial planning decisions are uniquely placed to help manage climate change impacts at a variety of scales but these decisions need to be underpinned by robust conceptual framing [13].

There are also potential difficulties in translating the new risk-based concept into practice, particularly in spatial planning which combines expertise from a range of disciplines. The definition of risk differs across disciplines and sectors $[14,15]$. In addition, existing climate change adaptation projects have used vulnerability-based conceptual frameworks, and there is therefore a question mark over the way that their resultant data can be easily reused now that risk-based approaches are being driven forwards. Essentially, whilst there has been much ink spilled over refining concepts, there are few examples of translating risk-based conceptions into practical projects with consideration of the challenges associated with using risk concepts in a climate change context.

This paper explores the move from a vulnerability-based framework to a risk-based framework. After outlining the underpinning components of vulnerability and risk, we demonstrate the utility of the risk-based framework suggested by the IPCC for spatial planning policy and practice. However, the latter half of the paper points to potential issues in the translation of climate change risk to broad adaptation policy and spatial planning. We conclude that the concept of risk helps cities to identify adaption options and build resilience to the changing climate by connecting across disaster risk management and climate change adaptation approaches. However, the conceptual mismatches-particularly around the notion of 'exposure'-have to be approached cautiously particularly with regard to spatial data [16]. The conceptual difficulties mean that there may be issues in deploying the use of geospatial and statistical classification techniques to spatially explore similarities and differences of cities in terms of their climate risk. This is important since the spatial understanding of risk could help decision makers prioritize climate risk and to help cities learn from one another.

\section{Materials and Methods}

The overall aim of the paper was to understand the implications of translating the IPCC's risk-based framework into practice, particularly in developing tools that could assist European cities in understanding their climate risk and to compare cities with one another. The thinking here was to lead to the development of a climate risk typology of European cities and regions within the Horizon 2020 RESIN project [17].

This entailed a literature review of the use of vulnerability and risk assessments in the climate change adaptation field. The literature search was made via Web of Science and Scopus using the terms 'vulnerability assessment' and 'risk assessment' with qualifiers around the field of 'climate change adaptation'. Papers were categorized based on the extent to which they were (a) conceptually 
oriented or (b) practically oriented. From this, it was possible to trace the transformation in the IPCC's conceptualization of vulnerability and risk. Practical papers were reviewed in order to enable a sense of the way in which the conceptual elements of vulnerability and risk were deployed in practice.

This paper then moves on to compare examples of European projects that have used either a vulnerability or a risk-based framework in order to isolate the similarities and differences between them, their strengths and limitations, and the extent to which they could be reused or reframed in terms of different concepts. There were a limited number of projects which employed a comparative pan-European methodology and so five were selected in order to balance across the differing assessment types (risk versus vulnerability) and the spatial scale to which they were applied.

\section{Results}

\subsection{Comparing Definitions}

Until recently, the vulnerability assessment of socio-ecological systems (SES) was the main focus of the climate change adaptation literature and was the approach adopted by the IPCC up to their Fourth Assessment Report (AR4). Vulnerability was defined as: 'The degree to which a system is susceptible to, or unable to cope with, adverse effects of climate change, including climate variability and extremes. Vulnerability is a function of the character, magnitude, and rate of climate variation to which a system is exposed, its sensitivity, and its adaptive capacity' [18] (p. 995). This can be expressed as a function: Vulnerability $=\mathrm{f}$ (Exposure, Sensitivity, Adaptive Capacity) and is visually outlined in Figure 1.

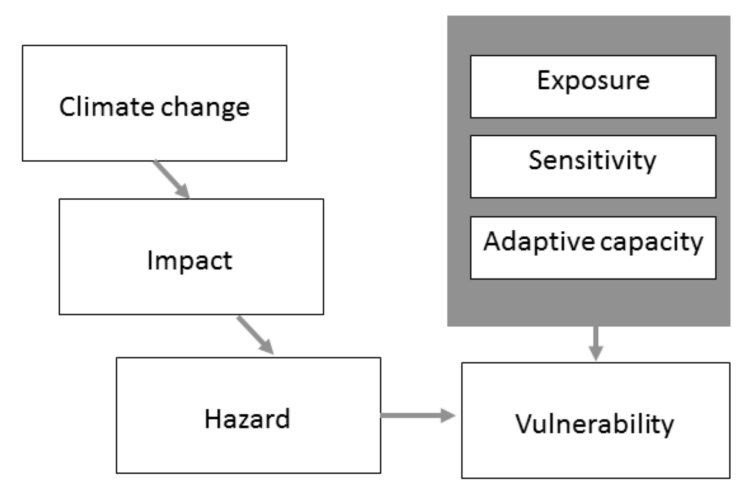

Figure 1. Pre-Intergovernmental Panel on Climate Change (IPCC) AR5 Conceptual Framing of Climate Change Vulnerability. Sensitivity: is 'the degree to which a system or species is affected, either adversely or beneficially, by climate variability or change' [19]; Exposure: is 'the nature and degree to which a system is exposed to significant climatic variations' where the exposure unit is 'an activity, group, region, or resource that is subjected to climatic stimuli' [18]; Adaptive Capacity: is the 'ability of systems, institutions, humans, and other organisms to adjust to potential damage, to take advantage of opportunities, or to respond to consequences' [18].

Here, climate change impacts upon a system. The degree to which that system is exposed in terms of the character and magnitude of climate change and the degree to which a given unit of analysis is affected combine to make an impact. Once the adaptive capacity of a system is subtracted, the residual figure would indicate the extent of the system's vulnerability. For example, a property may be considered as being exposed to flood risk and is more sensitive because of the existence of a basement. However, its vulnerability may be reduced because of the existence of early flood warning systems.

Vulnerability-based frameworks developed quickly. Within the climate change literature, the emphasis of early work (so-called 'first-generation') was on biophysical vulnerability which tends to focus on observed and projected changes in climate that may exacerbate exposure and sensitivity [20]. However, this could be criticized for privileging a 'science first' perspective to the detriment of implementing action. Thus, scholars began to draw attention to the ways in which 
existing socio-economic circumstances interact with climate change. This led to a distinction between outcome vulnerability ('the residual consequences that remain after adaptation has taken place') and contextual vulnerability ('a present inability to cope with external pressures or changes, such as changing climate conditions') [21,22]. As a result, subsequent IPCC reports paid attention to the way in which non-climatic drivers that also may affect vulnerability [23]. Critics pointed to a number of reasons why the framing of climate change in terms of vulnerability could be problematic. Vulnerability can be interpreted negatively and, thus, by labeling people and places as 'vulnerable', a passive attitude may be adopted to climate change. Similarly, the negative framing overlooks the importance of local culture and underlying resilience, particularly in non-western nations $[24,25]$. In short, a vulnerability frame can promote inaction [26].

The vulnerability framework also did not fit with other models available in the more present-day oriented disaster risk management literature, where the concept of risk predominates [27]. Given that climate change adaptation and disaster risk management have many overlaps, bringing the two approaches together is desirable in practice [28]. Amongst several other factors, this has led to the IPCC modifying their definition of vulnerability in AR5 by moving to a risk-based conceptual framework [6,22] (Figure 2).

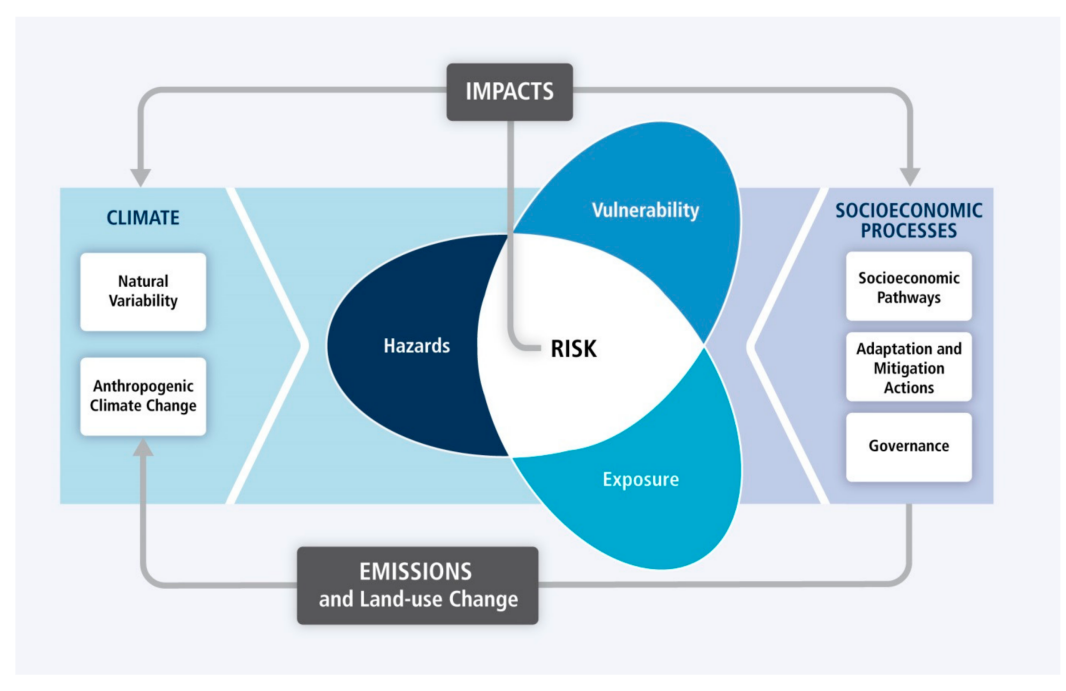

Figure 2. The IPCC AR5 conceptual framework with risk at the center [22].

Yet, risk is also a term that is difficult to define $[14,15]$ even though there is an international standard on risk management. IEC 31010 defines risk as the 'effect of uncertainty on objectives' [29]. An 'effect' is a positive and/or negative deviation from what is expected, whilst 'objectives' may be different aspects or goals. Furthermore, the standard considers risk in terms of an event's consequences combined with the likelihood of occurrence. Likelihood is the 'chance of something happening' and can be measured qualitatively or quantitatively [29]. In general terms, likelihood can be used interchangeably with probability. That said, probability more precisely refers to a quantifiable measurement where 'measure of the chance of occurrence [can be] expressed as a number between 0 and 1 , where 0 is impossibility and 1 is absolute certainty' [29].

This definition, albeit broad, results in a classic risk calculation whereby risk is the probability of an event with the consequences of an event:

$$
\text { Risk }=\text { Probability } \times \text { Consequences }
$$

Applying this risk conceptualization to the case of natural hazards can be problematic since the variables are not independent of one another: for example, the size of an event's impact influences the likelihood of occurrence [28]. That is, it is not the presence of a hazard that indicates the risk, 
rather, a hazard only becomes a risk when a system is exposed to the hazard and is vulnerable to it should it be exposed; thus, 'risk is also a function of the underlying environmental and socioeconomic context in which ... . climate change occurs' [30]. Moreover, whilst there are many examples of risk assessment methodological frameworks, these need to be fully cognizant of geographical variability, environmental processes and socio-economic vulnerability in order to be of use with respect to climate change [31]. For these reasons, the notions of vulnerability and exposure can usefully be introduced into the conceptualization of risk in order to capture these nuances. Therefore, as reflected in the IPCC AR5 approach, there is a functional relationship between the elements of risk, which are broken down to reflect the hazard, exposure, and vulnerability (Figure 2). Exposure and vulnerability combine as the consequences ('the impacts, if these [hazardous] events/trends occur') whilst probability relates to the hazard; or the 'probability of the occurrence of hazardous events/trends' [32].

$$
\text { Risk }(\mathrm{R})=f(\text { Probability of a Hazard }(\mathrm{p}), \times \text { Exposure }(\mathrm{E}), \times \text { Vulnerability }(\mathrm{V}))
$$

Table 1 compares and contrasts the key concepts between each knowledge area to explore the commonalities and differences. When those working within the pre-IPCC AR5 concepts refer to vulnerability, IPCC AR5 and disaster risk management understands this as risk. Similarly, vulnerability in IPCC AR5 equates to sensitivity and adaptive capacity within climate change studies (pre-IPCC AR5), or, for disaster risk management, simply 'sensitivity' [33].

The most important shift has occurred in the formulation of exposure, a concept that has not been well-defined in climate change adaptation studies [16,34]. The pre-IPCC AR5 considered the degree of exposure (that is, the degree to which railway tracks or electricity substations come into contact with a hazard as a consequence of the magnitude of climatic variation). IPCC AR5 modifies this to focus more on what is exposed (an electricity substation or railway tracks) (Table 1). This makes sense, particularly when thinking about critical infrastructure, because an electricity transmission line, for example, is only exposed to windstorms if it is above ground [35].

Since exposure has been removed from the understanding of vulnerability, the latter is now only composed of two components: sensitivity and adaptive capacity which, largely, retain the same definitions across AR4 and AR5. Risk is a newly introduced definition which tries to capture both the language of probability/consequence in addition to the spatial relationships between hazard, exposure and vulnerability. Whilst these concepts lend themselves well to the spatial identification of risk, the definitions are suitably open enough for divergent interpretations.

Table 1. Comparison of the conceptual elements of vulnerability and risk between IPCC pre-AR5 and AR5. All terms are drawn directly from the IPCC reports $[19,20]$.

\begin{tabular}{|c|c|c|}
\hline Term & IPCC pre-AR5 Definition & IPCC AR5 Definition \\
\hline Adaptive Capacity & $\begin{array}{l}\text { The ability of a system to adjust to climate } \\
\text { change (including climate variability and } \\
\text { extremes) to moderate potential damages, } \\
\text { to take advantage of opportunities, or to } \\
\text { cope with the consequences. }\end{array}$ & $\begin{array}{l}\text { The ability of people, institutions, organizations, } \\
\text { and systems, using available skills, values, beliefs, } \\
\text { resources, and opportunities, to address, manage, } \\
\text { and overcome adverse conditions in the short to } \\
\text { medium term. }\end{array}$ \\
\hline Exposure & $\begin{array}{l}\text { The nature and degree to which a system is } \\
\text { exposed to significant climatic variations. }\end{array}$ & $\begin{array}{l}\text { The presence of people, livelihoods, species or } \\
\text { ecosystems, environmental services and resources, } \\
\text { infrastructure, or economic, social, or cultural assets } \\
\text { in places that could be adversely affected. }\end{array}$ \\
\hline Hazard & No glossary definition & $\begin{array}{l}\text { The potential occurrence of a natural or } \\
\text { human-induced physical event or trend, or physical } \\
\text { impact, that may cause loss of life, injury, or other } \\
\text { health impacts, as well as damage and loss to } \\
\text { property, infrastructure, livelihoods, service } \\
\text { provision, and environmental resources. }\end{array}$ \\
\hline
\end{tabular}


Table 1. Cont.

\begin{tabular}{lll}
\hline Term & IPCC pre-AR5 Definition & IPCC AR5 Definition \\
\hline Risk & $\begin{array}{l}\text { The potential for consequences where something of } \\
\text { value is at stake and where the outcome is uncertain, } \\
\text { recognizing the diversity of values. Risk is often } \\
\text { represented as probability of occurrence of hazardous } \\
\text { events or trends multiplied by the impacts if these } \\
\text { events or trends occur. Risk results from the } \\
\text { interaction of vulnerability, exposure, and hazard. }\end{array}$ \\
\hline Sensitivity & $\begin{array}{l}\text { The degree to which a system or species is } \\
\text { affected, either adversely or beneficially, } \\
\text { by climate variability or change. }\end{array}$ & $\begin{array}{l}\text { The degree to which a system or species is affected, } \\
\text { either adversely or beneficially, by climate variability } \\
\text { or change. }\end{array}$ \\
\hline \multirow{3}{*}{$\begin{array}{l}\text { Vulnerability is a function of the character, } \\
\text { magnitude, and rate of climate variation to } \\
\text { which a system is exposed, its sensitivity, } \\
\text { and its adaptive capacity. }\end{array}$} & $\begin{array}{l}\text { The propensity or predisposition to be adversely } \\
\text { affected. Vulnerability encompasses a variety of } \\
\text { concepts including sensitivity or susceptibility to } \\
\text { harm and lack of capacity to cope and adapt. }\end{array}$ \\
\hline
\end{tabular}

\subsection{Comparing Risk/Vulnerability Assessments/Approaches}

Now, why do any of these conceptual changes matter? Quibbling over conceptual differences may seem pedantic in the face of the hard work of trying to implement climate resilient urban development. However, the framing of climate change, whether that be through the lens of 'vulnerability', 'risk' or 'resilience', is important because 'frames allow certain questions to be asked while others get silenced' [21,36] (p. 15). Furthermore, policy development is fundamentally hinged on how the concepts are framed: 'adaptation policy will be framed by how risk and vulnerability are conceptualized' [23]. It is recognized that the IPCC needed to bring in the language of risk in order to apply insights from related disciplines, particularly around impacts and vulnerabilities [7]. However, it is critical to ask what the implications of this change are, particularly in terms of spatial planning? Moreover, what role will impact and vulnerability assessments continue to play in the new conceptual landscape?

Impact and vulnerability assessments remain useful as elements of the risk assessment process in order to advance climate change adaptation and resilience goals. The differences between impact, vulnerability and risk assessments, and the functions that they perform in adaptation and resilience planning, are outlined in Table 2. It can be seen that impact, vulnerability and risk assessments are crucial to adapting and building resilience to climate change. However, neither impact nor vulnerability assessments consider the probability of occurrence of hazards, potential exposure to hazards, or the severity of related impacts. Risk assessments go beyond impact and vulnerability assessments and bring together different elements of the adaptation agenda (including impacts and vulnerability) to provide a basis for analyzing which weather and climate risks are most pressing. The resultant data on the IPCC's risk elements (hazard, exposure, vulnerability) can be useful separately; for example, in communicating hazard probabilities and informing measures to reduce vulnerability to hazards. The ability to deconstruct different risk elements offers additional insights to decision makers when planning adaptation responses, by identifying which issues are driving risk in a particular situation. However, it is when these elements are brought together within a risk assessment framework they become more powerful. This is particularly the case where supporting spatial data are available, as the elements of weather and climate risk vary according to location [37]. This approach is being taken forward within the Horizon 2020 RESIN project, which is developing a climate risk typology of European cities and regions [17].

Risk assessment is, therefore, a process that is focused on supporting decision-making. Brown and Wilby [38] describe analyzing climate risk as a matter of 'due diligence', which can be interpreted as taking a reasonable level of care before taking a decision. As Dickson et al. [39] suggest, this ties risk assessment closely to decision making; '... [risk] assessments aim to simplify complicated experiences of risk in order to assist in decision making'. 
The benefits of undertaking a risk assessment can also be observed in the outcomes of decisions informed by a risk-based approach, particularly where spatial risk data are available. Here, developing responses to minimize losses and negative impacts associated with climate change is key. Cities and urban areas face risks from a range of sources. Other risks, generated by socio-economic and bio-physical drivers of change, are equally as important as climate change when making decisions. The judgment on the precise influence of non-climatic drivers can be made if climate and non-climate risk information is available to be evaluated [10,40]. King et al. [41] (p. 8) highlight the importance of such an evaluation, noting that; 'The most important decision that any government has to make about climate change is one of priority: how much effort to expend on countering it, relative to the effort that must be spent on other issues'.

Table 2. Differences between impact, vulnerability, and risk assessments.

\begin{tabular}{|c|c|c|c|}
\hline & Impact Assessment & Vulnerability Assessment & Risk Assessment \\
\hline Inputs & $\begin{array}{l}\text { Impact assessments require details of } \\
\text { weather and climate hazards and the } \\
\text { natural and human systems with the } \\
\text { potential to be affected. }\end{array}$ & $\begin{array}{l}\text { Sensitivity and adaptive capacity data are } \\
\text { needed to undertake a vulnerability } \\
\text { assessment, based on the IPCC's } \\
\text { AR5 approach. }\end{array}$ & $\begin{array}{l}\text { The IPCC's AR5 risk approach focuses on } \\
\text { the interaction between hazard, exposure } \\
\text { and vulnerability. Data are required on } \\
\text { these themes to complete an assessment. }\end{array}$ \\
\hline Outputs & $\begin{array}{l}\text { Potential weather and climate impacts to } \\
\text { natural and human systems. Cascading } \\
\text { impacts, within and between systems, } \\
\text { are significant yet can be difficult to } \\
\text { establish due limited data and } \\
\text { modeling capacity. }\end{array}$ & $\begin{array}{l}\text { Details of the vulnerability of 'receptors' } \\
\text { to weather and climate hazards. } \\
\text { Data permitting, vulnerability can be } \\
\text { mapped spatially. }\end{array}$ & $\begin{array}{l}\text { Identification of weather and climate } \\
\text { risks. Data permitting, risk assessment } \\
\text { outputs can be mapped spatially. }\end{array}$ \\
\hline Issues & $\begin{array}{l}\text { Impact assessments generally provide no } \\
\text { indication of the probability of impacts } \\
\text { occurrence. Impact severity, which } \\
\text { relates factors including hazard intensity } \\
\text { and the vulnerability of the system to the } \\
\text { event, is not commonly considered. }\end{array}$ & $\begin{array}{l}\text { Adaptation responses can be developed to } \\
\text { reduce vulnerability. } \\
\text { However, without details of the probability } \\
\text { of, and potential spatial exposure to, } \\
\text { hazards, the effectiveness of responses to } \\
\text { moderate vulnerability is reduced. }\end{array}$ & $\begin{array}{l}\text { Risk assessments provide a picture of } \\
\text { priority risks, in terms of their probability } \\
\text { and consequence, enabling available } \\
\text { response capacity and resources to be } \\
\text { targeted more effectively. }\end{array}$ \\
\hline
\end{tabular}

\subsection{Comparing the Application of Risk/Vulnerability Assessments/Approaches}

Having established the utility of a risk assessment versus a vulnerability-based assessment approach, we now turn to some of the problems that may be encountered by the movement from vulnerability to risk in climate change adaptation studies. Table 3 outlines existing climate change assessment projects. The ESPON typology, for example, lacks depth in terms of the scope of hazard, exposure, vulnerability or adaptive capacity indicators to provide an effective framework for understanding spatial risk. Given that it is based on the earlier AR4 conception, the ESPON work can only indicate vulnerability rather than taking further measures to identify and prioritize risk based on the vulnerabilities. There is also limited granularity which is unhelpful for adaptation planning-the five groups of the typology are based on geographical and climate data which do not have much analytical purchase ('science-first' vulnerability perspective). Although offering better granularity than ESPON, the European Environment Agency's (EEA) Urban Vulnerability Map is limited by a focus on present-day vulnerabilities only and a limited set of indicators because of inconsistent data coverage across all European countries. Therefore, the Urban Vulnerability Map can only offer cities a route into the early stages of adaptation planning where potential applications are scoped out. The Reconciling Adaptation, Mitigation and Sustainable Development for Cities (RAMSES) project utilizes risk concepts in order to harmonize with AR5. However, RAMSES focuses only on 571 cities contained within the EU's Urban Audit. Whilst this is understandable, the perspective is limited to specific cities and also ignores the wider hinterland that a city might be embedded within; a particularly important consideration for progressing climate change adaptation. Finally, the risk-based conception was utilized in the Adaptation Strategies for Climate Change in the Urban Environment (ASSCUE) project over a decade ago with success. However, the methodologies are applicable at neighborhood and conurbation scale. The project was also based on the UK only and on the spatial unit of the urban morphology type which limits comparability across other cities and regions. 
Table 3. Comparison of European risk- and vulnerability-based projects.

\begin{tabular}{|c|c|c|c|c|}
\hline Project (Year) & Brief Description & Conceptualization & Spatial Unit & Gaps \\
\hline ASSCUE (2006) [42] & $\begin{array}{l}\text { The ASSCUE project looked at } \\
\text { the impacts of climate change } \\
\text { on towns and cities in the UK. } \\
\text { ASSCUE considered the } \\
\text { concept of risk in order to } \\
\text { underpin the development of } \\
\text { conurbation and neighborhood } \\
\text { scale adaptation strategies. }\end{array}$ & Risk & Urban Morphology Types & $\begin{array}{l}\text { Limited comparability-based } \\
\text { on UK only and at conurbation } \\
\text { and neighborhood scale }\end{array}$ \\
\hline ESPON (2011) [43] & $\begin{array}{l}\text { ESPON developed a typology } \\
\text { of European regions based on } \\
\text { their vulnerability to climate } \\
\text { change, their adaptive capacity, } \\
\text { and the impact that climate } \\
\text { change may have on } \\
\text { the economy. }\end{array}$ & Vulnerability & NUTS 3 & $\begin{array}{l}\text { Limited data availability. } \\
\text { Different use of the term } \\
\text { exposure. Limited to a typology } \\
\text { based on climate and geography; } \\
\text { not socio-economic issues } \\
\text { (although socio- economic } \\
\text { indicators are mapped). }\end{array}$ \\
\hline PESETA II (2014) [44] & $\begin{array}{l}\text { The JRC PESETA II project } \\
\text { (Projection of Economic } \\
\text { impacts of climate change in } \\
\text { Sectors of the European Union } \\
\text { based on bottom-up Analysis) } \\
\text { aimed to understand the spatial } \\
\text { effects of the biophysical and } \\
\text { social impacts of climate } \\
\text { change on European regions } \\
\text { and also for different sectors. }\end{array}$ & Vulnerability & NUTS 2 & $\begin{array}{l}\text { Limited to a focus on climate } \\
\text { and economic impacts. }\end{array}$ \\
\hline $\begin{array}{l}\text { EEA Urban Vulnerability } \\
\text { Map (2015) [45] }\end{array}$ & $\begin{array}{l}\text { This EEA's map book provides } \\
\text { a Europe-wide overview of the } \\
\text { potential vulnerability of major } \\
\text { European urban areas to } \\
\text { climate change by highlighting } \\
\text { areas of potential weakness. }\end{array}$ & Vulnerability & $\begin{array}{l}\text { EU-OECD Classification } \\
\text { of Cities }\end{array}$ & $\begin{array}{l}\text { Limited set of indicators. } \\
\text { Focused on present-day. }\end{array}$ \\
\hline RAMSES (2016) [37] & $\begin{array}{l}\text { RAMSES developed risk } \\
\text { assessment tools using existing } \\
\text { data. A top-down, indicator } \\
\text { approach identified climate } \\
\text { risks for } 571 \text { European cities as } \\
\text { contained in the Urban Audit. }\end{array}$ & Risk & $\begin{array}{l}\text { EU-OECD Classification } \\
\text { of Cities }\end{array}$ & $\begin{array}{l}\text { Limited set of indicators. } \\
\text { Limited number of cities. }\end{array}$ \\
\hline
\end{tabular}

Retrofitting extant data may be problematic. For example, the ESPON project produced supporting data on the Territorial Effects of Climate Change on European Cities [43]. Underpinning the report was spatial data that resulted in the broad identification of five 'climatic types'. The data are at NUTS 3 level and includes data for climatic conditions and the pre-AR5 vulnerability concepts of exposure, sensitivity and adaptive capacity. The data are available for reuse. However, examination of these data entails detailed considerations of how the concepts were developed to ensure that it remains of use today. ESPON's exposure indicators measure change in a hazard (e.g., changes in annual mean temperature), which corresponds with AR5's 'hazard'. Similarly, ESPON's sensitivity data indicate susceptibility to harm insofar as a receptor is located (AR5's 'exposure') in the presence of an exposure element (AR5's hazard). ESPON [41] then combines sensitivity and exposure to create an impact which, with the addition of adaptive capacity, gives overall vulnerability scores. The sensitivity indicators comprise physical sensitivity, cultural sensitivity, social sensitivity, environmental sensitivity and economic sensitivity. All but the economic sensitivity data are spatial. It is not that the data cannot be reused, but a process of working through the definitions and analyzing the indicators is required in order to reframe and repackage them in order to be useful to the AR5 concepts. It is surely a waste of resources to compile new datasets where significant effort has been made to commission and promote the original ones. Exposure indicators may be used as 'Hazard' whilst some, but not all, of the sensitivity indicators can be used to represent 'Exposure'.

\section{Discussion}

There are a number of reasons why the concept of risk, and the undertaking of risk assessments, has advantages over vulnerability-driven terminology and related assessments. Conceptually, separating out exposure can be beneficial to spatial planners as it emphasizes the worth and spatial targeting of exposure reduction measures (e.g., not building in flood risk areas). Conversely, a focus only on probability and consequences tends to privilege the construction of more 
robust flood defenses [46]. The separation of exposure from vulnerability helps decision makers prioritize actions that can either reduce exposure to a hazard, or else reduce vulnerability through measures that address sensitivity and adaptive capacity. It also moves the climate change adaptation community closer to models that have been used in disaster risk management and, in turn, the insurance industry [31].

An example can help to illustrate this. In order to understand the risk of flooding to a building, it is necessary to understand whether the building is exposed (spatially) to the flood in the first place. Further accentuating the risk may be particular factors that make a building sensitive to flooding (such as the presence of basement floors). The risk may be less if adaptive capacity is high; the existence of early flood warning systems is an example here. Given the understanding of the different elements of risk, a decision maker can then prioritize actions based on:

- Reduce greenhouse gas emissions to lessen the frequency and severity of future hazards

- Undertaking adaptation measures that reduce exposure (by relocating the building outside the potentially flooded area)

- Undertaking adaptation measures that reduce sensitivity (by making sure that vulnerable groups or activities are not housed in that building)

- Undertaking adaptation measures that increasing adaptive capacity (by installing flood mitigation measures for the building; presence of early warning systems).

Risk assessments focus attention on the highest risks, the locations where risks are most prominent, and enable the relative significance of climate and non-climate related risks to be determined. Here, the risk assessment is narrowing or helping to prioritize the range of possible risks to consider and clarifying the objectives of the adaptation planning process. In turn this can help to direct attention to the allocation of available capacity and resources for climate change adaptation and resilience building. Risk assessments also help to fill knowledge gaps by increasing understanding of the probability and consequence of different risks: 'one of the key purposes of risk assessment is to allow decision-makers to weigh choices for action under uncertainty' [41] (p. 23). Risk assessment can help to illuminate the implications of different decision options when responding to climate risk, which may include a decision not to act and therefore to accept the identified risk(s).

Risk assessment processes (and therefore outcomes) are affected by uncertainty. For example, uncertainty in climate projections must be recognized within any analysis of the probability of occurrence of hazard events. Here, it is important to be clear as to which dimensions of uncertainty risk assessment can respond. Addressing this point, Willows and Connell [40] (p. 48) note that, 'risk assessment deals explicitly with uncertainty in decision-making rather than giving an over-confident view of what is known.' Climate change risk assessments do not reduce uncertainty associated with climate change, but the process can support decision makers in analyzing the consequences of an (uncertain) changing climate in order to focus and target strategies and actions in response.

Risk connects across the science-policy interface in the climate change adaptation and resilience world. Science-based assessments of risk feed into the policy arena, where a range of issues (including climate and non-climate risks) then compete to influence decisions. As a result, it is necessary to acknowledge that the identification of significant climate related risk may not stimulate action, even when the decision-making process is driven by climate change. Decision makers may perceive addressing other issues and risks as a higher priority.

Ultimately, risk assessments, particularly when applied spatially, can be much more powerful in helping decision makers to prioritize climate risk and to develop tailored adaptation strategies relating to spatial planning. There have already been significant research projects that have helped to advance the state of climate change adaptation knowledge in cities. However, there are problems in terms of their spatial reference point, the data that they draw on, and their understanding of the term 'exposure', which has thus far inhibited comparability. In order to advance the aim of prioritizing climate risk, and facilitating knowledge sharing between cities, a number of knowledge gaps that will need to be 
addressed in future research. For example, further comparative work utilizing the latest advances in geospatial techniques could assist in the development of a strategic screening tool that can be applied at the beginning of a longer process of urban adaptation planning to inform tasks, including adaptation options development and peer-to-peer learning. This could reflect urban risk to climate change by capturing the domains of hazards, exposure, sensitivity, and adaptive capacity. Such comparative work should also be underpinned by recognizing that cities are embedded within a wider urban hinterland and should aim for a systems perspective to acknowledge the integrated impacts of climate risks as well as the temporal and spatial variability of climate risks. Lastly, risk assessments need to draw on an already rich tradition in risk communication in order to ensure that the uncertainties associated with climate change are properly communicated to end-users with associated advice for interpretation and application.

\section{Conclusions}

In conclusion, we argue that the spatial assessment of risk is important for targeting adaptation responses and is particularly useful in the field of spatial planning. However, finding spatial data to follow a risk-based assessment approach is difficult and there is a gap in knowledge on the risk to cities from climate change and the potential adaptation responses. Prior applications of vulnerability assessments, which are based on earlier conceptual framings, may potentially have data that could be reused. However, there needs to be a careful translation of the concepts in order to reuse the data. In terms of the risk-based framing of climate change, there is further work to be done on understanding how appropriate spatial data can be developed and shared.

Author Contributions: Conceptualization—all authors; Methodology—all authors; Formal Analysis-Angela Connelly and Jeremy Carter; Writing Original Draft Preparation-Angela Connelly and Jeremy Carter; Writing Reviewing and Editing-All Authors; Project Administration-Jeremy Carter; Funding Acquisition-Jeremy Carter.

Funding: This research was funded by the European Union's Horizon 2020 research and innovation programme, grant agreement no. 653522.

Acknowledgments: The authors want to thank members of the RESIN project consortium for in-depth discussions around this topic. The authors also wish to thank the two anonymous reviewers whose comments helped to improve the paper.

Conflicts of Interest: The authors declare no conflict of interest.

\section{References}

1. Denton, F.; Wilbanks, T.J.; Abeysinghe, A.C.; Burton, I.; Gao, Q.; Lemos, M.C.; Warner, K. Climate-resilient pathways: Adaptation, mitigation, and sustainable development. In Climate Change 2014: Impacts, Adaptation, and Vulnerability; Cambridge University Press: Cambridge, UK, 2014; pp. 1101-1131.

2. United Nations Environment Programme (UNEP). Sustainable Development Goal 13: Take Urgent Action to Combat Climate Change and Its Impacts. Available online: http:/ / web.unep.org/nairobiconvention/ sustainable-development-goal-13-take-urgent-action-combat-climate-change-and-its-impacts (accessed on 20 April 2018).

3. Bithas, K.P.; Christofakis, M. Environmentally sustainable cities. Critical review and operational conditions. Sustain. Dev. 2006, 14, 177-189. [CrossRef]

4. Camagni, R.; Capello, R.; Nijkamp, P. Towards sustainable city policy: An economy-environment technology nexus. Ecol. Econ. 1998, 24, 103-118. [CrossRef]

5. Kelman, I.; Gaillard, J.C.; Mercer, J. Climate Change's Role in Disaster Risk Reduction's Future: Beyond Vulnerability and Resilience. Int. J. Disaster Risk Sci. 2015, 6, 21-27. [CrossRef]

6. Intergovernmental Panel on Climate Change (IPCC). Managing the Risks of Extreme Events and Disasters to Advance Climate Change Adaptation; A Special Report of Working Groups I and II of the Intergovernmental Panel on Climate Change; Field, C.B., Barros, V., Stocker, T.F., Qin, D., Dokken, D.J., Ebi, K.L., Mastrandrea, M.D., Mach, K.J., Plattner, G., Allen, S.K., et al., Eds.; Cambridge University Press: Cambridge, UK, 2012.

7. Pelling, M. Adaptation to Climate Change: From Resilience to Transformation; Routledge: London, UK; New York, NY, USA, 2011. 
8. Aven, T.; Renn, O. An Evaluation of the Treatment of Risk and Uncertainties in the IPCC Reports on Climate Change. Risk Anal. 2015, 35, 701-712. [CrossRef] [PubMed]

9. Meadow, A.M.; Ferguson, D.B.; Guido, Z.; Horangic, A.; Owen, G.; Wall, T. Moving Toward the Deliberate Coproduction of Climate Science Knowledge. Weather Clim. Soc. 2015, 7, 179-191. [CrossRef]

10. Weaver, C.P.; Moss, R.H.; Ebi, K.L.; Gleick, P.H.; Stern, P.C.; Tebaldi, C.; Wilson, R.S.; Arvai, J.L. Reframing Climate Change Assessments Around Risk: Recommendations for the US National Climate Assessment. Environ. Res. Lett. 2017, 12, 80201. [CrossRef]

11. Wilson, E.; Piper, J. Spatial Planning and Climate Change; Taylor \& Francis: London, UK, 2010.

12. Schmidt-Thome, P.; Greiving, S. European Climate Vulnerabilities and Adaptation: A Spatial Planning Perspective; John Wiley \& Sons: Chichester, UK, 2010.

13. Carter, J.G.; Cavan, G.; Connelly, A.; Guy, S.; Handley, J.; Kázmierczak, A. Climate Change and the City: Building Capacity for Urban Adaptation. Progress Plan. 2015, 95, 1-66. [CrossRef]

14. Thywissen, K. Components of Risk: A Comparative Glossary (Studies of the University: Research, Counsel, Education); UNU Institute for Environment and Human Security: Bonn, Germany, 2006.

15. Wolf, S. Vulnerability and risk: Comparing assessment approaches. Natl. Hazards 2011, 61, 1099-1113. [CrossRef]

16. Jurgilevich, A.; Räsänen, A.; Groundstroem, F.; Juhola, S. A Systematic Review of Dynamics in Climate Risk and Vulnerability Assessments. Environ. Res. Lett. 2017, 12, 13002. [CrossRef]

17. Climate Resilient Cities and Infrastructure (RESIN) Project. 'About RESIN'. Available online: http:/ / www. resin-cities.eu/home/ (accessed on 1 May 2018).

18. Intergovernmental Panel on Climate Change (IPCC). Climate Change 2001: The Scientific Basis. Contribution of Working Group I to the Third Assessment Report of the Intergovernmental Panel on Climate Change; Houghton, J.T., Ding, Y., Griggs, D.J., Noguer, M., Van der Linden, P.J., Dai, X., Maskell, K., Johnson, C.A., Eds.; Cambridge University Press: Cambridge, UK; New York, NY, USA, 2001.

19. Intergovernmental Panel on Climate Change (IPCC). Annex II: Glossary. In Climate Change 2014: Synthesis Report. Contribution of Working Groups I, II and III to the Fifth Assessment Report of the Intergovernmental Panel on Climate Change; Core Writing Team, Pachauri, R.K., Meyer, L.A., Eds.; IPCC: Geneva, Switzerland, 2014; pp. 117-130.

20. Füssel, H.-M.; Klein, R.J.T. Climate Change Vulnerability Assessments: An Evolution of Conceptual Thinking. Clim. Chang. 2006, 75, 301-329. [CrossRef]

21. O'Brien, K.; Eriksen, S.; Nygaard, L.P.; Schjolden, A. Why Different Interpretations of Vulnerability Matter in Climate Change Discourses. Clim. Policy 2007, 7, 73-88. [CrossRef]

22. Intergovernmental Panel on Climate Change (IPCC). Climate Change 2014: Impacts, Adaptation, and Vulnerability. Part A: Global and Sectoral Aspects. Contribution of Working Group II to the Fifth Assessment Report of the Intergovernmental Panel on Climate Change; Field, C.B., Barros, V.R., Dokken, D.J., Mach, K.J., Mastrandrea, M.D., Bilir, T.E., Chatterjee, M., Ebi, K.L., Estrada, Y.O., Genova, R.C., et al., Eds.; Cambridge University Press: Cambridge, UK; New York, NY, USA, 2014.

23. Bassett, T.J.; Fogelman, C. Déjà vu or something new? The Adaptation Concept in the Climate Change Literature. Geoforum 2013, 48, 42-53. [CrossRef]

24. Bankoff, G. Rendering the World Unsafe: 'Vulnerability' as Western Discourse. Disasters 2001, 25, 19-35. [CrossRef] [PubMed]

25. Giupponi, C.; Biscaro, C. Vulnerabilities-Bibliometric Analysis and Literature Review of Evolving Concepts. Environ. Res. Lett. 2015, 10, 123002. [CrossRef]

26. UNISDR. Terminology on Disaster Risk Reduction (No. The United Nations Office for Disaster Risk Reduction). 2009. Available online: http:/ / www.unisdr.org/we/inform/terminology (accessed on 5 July 2016).

27. European Environment Agency (EEA). Urban Adaptation to Climate Change in Europe: Challenges and Opportunities for Cities Together with Supportive National and European Policies (No. 2/2012); European Environment Agency: Copenhagen, Denmark, 2012.

28. International Organisation for Standardisation (IOS)/International Electrotechnical Commission (IEC). Risk Management_Risk Assessment Techniques (IEC 31010); IEC: Geneva, Switzerland, 2009.

29. European Commission. Commission Staff Working Paper: Risk Assessment and Mapping Guidelines for Disaster Management (No. SEC (2010) 1626); European Commission: Brussels, Belgium, 2010. 
30. Preston, B.L.; Jones, R.N. Screening Climatic and Non-Climatic Risks to Australian Catchments. Geogr. Res. 2008, 46, 258-274. [CrossRef]

31. Lindley, S.J.; Handley, J.F.; Theuray, N.; Peet, E.; McEvoy, D. Adaptation Strategies for Climate Change in the Urban Environment: Assessing Climate Change Related Risk in UK Urban Areas. J. Risk Res. 2006, 9, 543-568. [CrossRef]

32. Birkmann, J.; Cardona, O.D.; Carreño, M.L.; Barbat, A.H.; Pelling, M.; Schneiderbauer, S.; Kienberger, S.; Keiler, M.; Alexander, D.E.; Zeil, P.; et al. Theoretical and Conceptual Framework for the Assessment of Vulnerability to Natural Hazards and Climate Change in Europe: The MOVE Framework. In Assessment of Vulnerability to Natural Hazards; Elsevier: Amsterdam, The Netherlands, 2014; Chapter 1; pp. 1-19.

33. Kázmierczak, A.; Handley, J. The Vulnerability Concpet: Use within GRaBS. 2001. Available online: https: / / nanopdf.com/download/the-vulnerability-concept-use-within-grabs_pdf (accessed on 25 March 2018).

34. Räsänen, A.; Juhola, S.; Nygren, A.; Käkönen, M.; Kallio, M.; Monge, A.M.; Kanninen, M. Climate Change, Multiple Stressors and Human Vulnerability: A Systematic Review. Reg. Environ. Chang. 2016, 16, 2291-2302. [CrossRef]

35. McCord, M.; Rodgers, J.; Davis, P.; Haran, M.; Berchtold, C. SOTA Gaps and Guidance Parameters for all WP's, INTACT Deliverable D1.1, Project Co-funded by the European Commission under the 7th Framework Programme, 2015. Available online: http://www.intact-project.eu/intact/assets/File/wp/D1_1_SOTA_ gaps.pdf (accessed on 25 March 2018).

36. Fünfgeld, H.; McEvoy, D. Framing Climate Change Adaptation in Policy and Practice. (VCCCAR Project: Framing Adaptation in the Victorian Context No. Working Paper 1). Victorian Centre for Climate Change Adaptation Research: Melbourne, 2011. Available online: http://www.climateaccess.org/sites/default/files/Funfgeld_ Framing\%20Climate\%20Adaptation\%20in\%20Policy\%20and\%20Practice.pdf (accessed on 25 March 2018).

37. Tapia, C.; Guerreiro, S.; Mendizabal, M.; Kilsby, C.; Feliu, E.; Glenis, V.; Dawson, R.; Eluwa, C. High Level Quantified Assessment of Key Vulnerabilities and Priority Risks for Urban Areas in the EU (No. D3.1), the RAMSES Project, 2015. Available online: http:/ / www.climateaccess.org/sites/default/files/Funfgeld_ Framing\%20Climate\%20Adaptation\%20in\%20Policy\%20and\%20Practice.pdf (accessed on 20 April 2018).

38. Brown, C.; Wilby, R.L. An alternate approach to assessing climate risks. Eos Trans. AGU 2012, 93, 401-402. [CrossRef]

39. Dickson, E. Urban Risk Assessments: Understanding Disaster and Climate Risk in Cities; World Bank Publications: Washington, DC, USA, 2012.

40. Willows, R.; Connell, R. (Eds.) Climate Adaptation: Risk, Uncertainty and Decision-Making; UKCIP Technical Report; UK Climate Impacts Programme: Oxford, UK, 2003.

41. King, D.; Schrag, D.; Zhou, D.; Ye, Q.; Ghosh, A. Climate Change: A Risk Assessment; Centre for Science and Policy: Cambridge, UK, 2016.

42. Adaptation Strategies for Climate Change in the Urban Environment (ASSCUE) Project. Project description. Available online: http:/ / climate-adapt.eea.europa.eu/metadata/projects/adaptation-strategies-for-climatechange-in-the-urban-environment (accessed on 1 May 2018).

43. ESPON Climate. Climate Change and Territorial Effects on Regions and Local Economies. Final Report. ESPON \& IRPUD, TU Dortmund, 2011. Available online: https:/ /www.espon.eu/export/sites/default/ Documents/Projects / AppliedResearch/CLIMATE/ESPON_Climate_Final_Report-Part_B-MainReport. pdf (accessed on 25 March 2018).

44. European Union (EU) Science Hub. Projection of Economic Impacts of Climate Change in Sectors of the EU based on Bottom-up Analysis (PESETA) II. Available online: https:/ / ec.europa.eu/jrc/en/peseta/reports (accessed on 1 May 2018).

45. European Environment Agency (EEA). Urban Vulnerability to Climate Change in Europe-An Interactive Map Book. Available online: http://climate-adapt.eea.europa.eu/knowledge/tools/urban-adaptation/ introduction (accessed on 1 May 2018).

46. Klijn, F.; Kreibich, H.; de Moel, H.; Penning-Rowsell, E. Adaptive Flood Risk Management Planning Based on a Comprehensive Flood Risk Conceptualisation. Mitig. Adapt. Strateg. Glob. Chang. 2015, 20, 845-864. [CrossRef]

(C) 2018 by the authors. Licensee MDPI, Basel, Switzerland. This article is an open access article distributed under the terms and conditions of the Creative Commons Attribution (CC BY) license (http://creativecommons.org/licenses/by/4.0/). 